\title{
First Report of Lernaea cyprinacea (Copepoda: Lernaeidae) on Rainbow Trout (Oncorhynchus mykiss) from the Sarı Mehmet Dam Lake in Van-Turkey
}

\author{
Cigdem Urku ${ }^{1 *}$, Sukru Onalan ${ }^{2}$ \\ 'Istanbul University, Faculty of Aquatic Science, Department of Fish Diseases, Istanbul, Turkey \\ ${ }^{2}$ Yüzüncü YIl University, Faculty of Fisheries, Department of Fish Diseases, Van, Turkey
}

Please cite this article as: Urku C, Onalan S. First Report of Lernaea cyprinacea (Copepoda: Lernaeidae) on Rainbow Trout (Oncorhynchus mykiss) from the Sarı Mehmet Dam Lake in Van-Turkey. Eur J Biol 2018; 77(1): 42-5.

\begin{abstract}
Objective: This report focuses on the diagnosis of rainbow trout mortality in the Sarı Mehmet Dam Lake.

Materials and Methods: The ten rainbow trout (Oncorhynchus mykiss) (300 - $350 \mathrm{~g}$ ) examined were infested with numerous copepod parasites which were attached to body muscles especially in the caudal and abdominal area.

Results: According to morphological results, this parasite was identified as L. cyprinacea. Histopathological examination of lesions revealed inflammatory response in the dermis and skeletal muscles and infectious granuloma.

Conclusion: This paper is the first to describe cases of lernaeosis on the rainbow trout (O. mykiss) from the Sarı Mehmet Dam Lake in Van-Turkey.

Keywords: Anchor worm, Lernaea cyprinacea, Rainbow trout, histopathology
\end{abstract}

\section{INTRODUCTION}

Lernaea cyprinacea, is a common parasite and appears almost all over the world in freshwater fish (1-3), and has been isolated from 46 species of Cyprinidae. Lernaea (Cyclopoida: Lernaeidae), or anchor worms, cause lernaeosis and are parasitic copepod found on the skin and gills of freshwater fish $(3,4)$. There are various Lernaea species but the most common species, Lernaea cyprinacea is known as an opportunistic ectoparasite of fresh water fish species, especially crucian carp (Carassius carassius) and occasionally on tadpoles of amphibians (4-6). According to Grabda (7), the rainbow trout (O. mykiss) is very sensitive to $L$. cyprinacea. This parasite is known to parasitize more than 100 hosts (8). It is thought to have spread with cyprinid hosts (9). During a recent survey, L. cyprinacea was recorded on various native fish species $(3,10,11)$.

The parasite attaches itself to fish with an anchor, feeding on fish blood and tissue debris in this way, and macroscopically, causing the loss of scales, oedema on the skin, haemorrhages and deep ulcers and, thus, the parasite forms routes of entry for other pathogen such as fungi and bacteria causing secondary infection
$(8,12)$. This parasite can cause the mass death of infected fish but Abbas et al. (13) reported that young fish are more sensitive to infestation. Specifically, in salmonids, L. cyprinacea was observed in stocked rainbow trout $(O$. mykiss) (12) and Salmo spp. (8).

Histopathologically, significant pathological lesions were reported in the skin, gills and eyes but pathological lesions have been observed in the visceral organs of the small fish such as the liver and kidney (14). Generally, this parasite causes granulomatous reactions, degeneration and necrosis in the skeletal muscle; inflammatory reactions in the subcutaneous tissue; hyperplasia and necrosis of gill epithelium; oedema and congestion and haemorrhages in the affected areas such as skeletal muscle and skin (11,12,14-16).

There are many studies about lernaeosis in Turkey $(10,17-23)$. However, there is no report about lernaeosis on the rainbow trout from the Sarı Mehmet Dam Lake-Van. The aim of the study was the diagnosis of $L$. cyprinacea infestation in rainbow trout and describes the histopathology of infected tissue such as skin, eyes, gills and other tissues. 


\section{MATERIAL AND METHODS}

\section{Fish Sampling and Parasitological Analysis}

The fish samples were collected from the Sarı Mehmet Dam Lake in the province of Özalp / Van $\left(38^{\circ} 48^{\prime} 15^{\prime \prime} \mathrm{N}\right.$ and $43^{\circ} 48^{\prime} 37^{\prime \prime} \mathrm{E}$ in October (Figure 1). Ten moribund rainbow trout (300-350 g) were examined micro- and macroscopically for the detection of the parasite. For this purpose, the parasites were carefully removed from the skin (24). Anchor worms were examined under a light microscope for diagnosis. The parasite was identified following the Bauer Method (25).

\section{Histopathology}

All infected fish were subjected to necropsy and preserved in $10 \%$ buffered formalin solution for histopathological examination. Fixed tissue samples were embedded in paraffin, dehydrated, sectioned at 4-5 $\mu \mathrm{m}$, stained with haematoxylin and eosin (H\&E) and examined with a light microscope (26).

\section{RESULTS}

\section{Clinical Findings}

At the time of the fish sampling, the water temperature was measured as $23^{\circ} \mathrm{C}, \mathrm{pH}$ 8.6. During sampling, ten rainbow trout were collected. All fish clearly showed haemorrhagic and ulcerative skin lesions (Figure $2 \mathrm{a}$ ), loss of scales and also oedema (Figure 2b) especially on the attachment areas of the parasites. The parasites attached to infected fish with anchors were determined macroscopically on various parts of the body. The attachment area of the parasite was mainly in the caudal and abdominal regions.

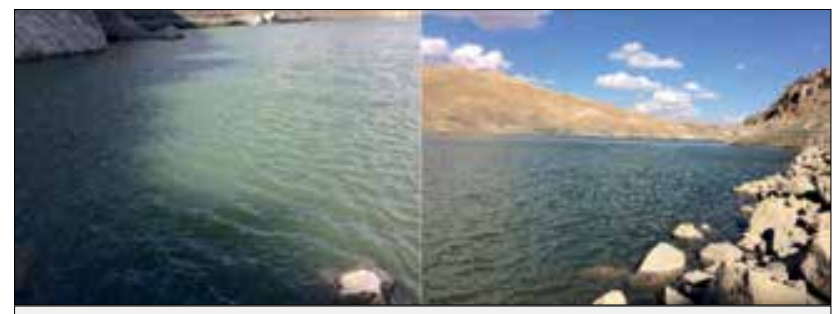

Figure 1: Sampling area in the Sarı Mehmet Dam Lake-Van

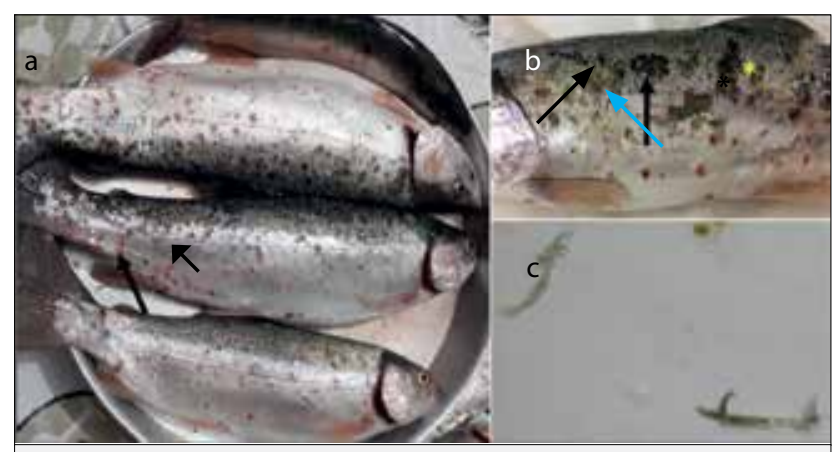

Figure 2. Rainbow trout infected with L. cyprinacea. Haemorrhages and ulcerative skin lesions on the attachment areas of the parasites (arrowed) (a), loss of scales (arrowed) and oedema

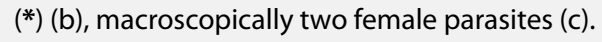

\section{Parasitological Findings}

In the parasitological examination, a large number of female parasites were found macroscopically and microscopically, the parasite was identified as female $L$. cyprinacea, with two egg sacs and a length range of $15-17 \mathrm{~mm}$ (Figure $2 \mathrm{c}$ ).

\section{Histopathological Findings}

Histopathologically, significant pathological lesions were reported in the skin, gills, eyes, and, most surprisingly, in the intestine. In the histopathologic examination of the tissues of rainbow trout infected with L. cyprinacea, hyperplasia, an increase in mucous cells in the distal end of primary lamella, vacuolization in secondary lamella, necrosis of gill epithelium, distortion in cartilaginous tissue (Figure 3a), haemorrhages and hyper-

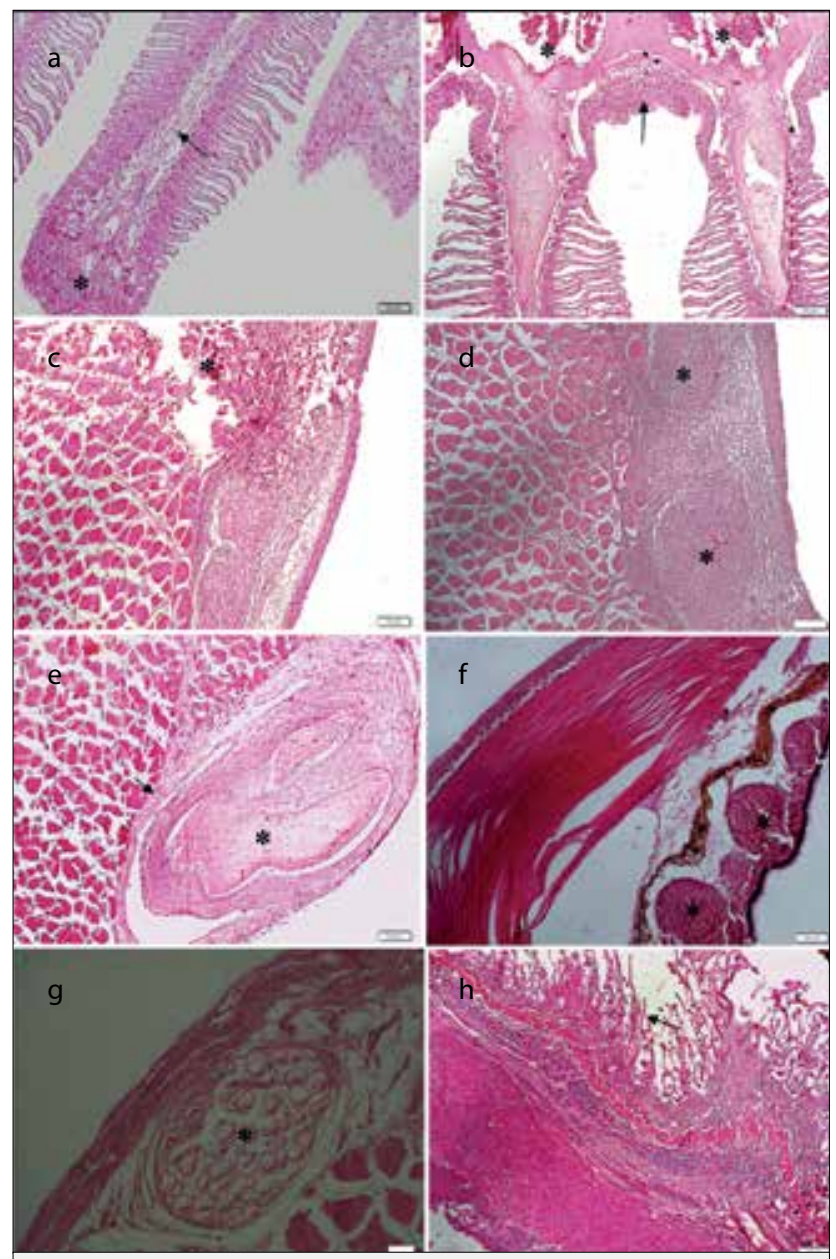

Figure 3. a-h. In the histopathologic examination of the tissues of rainbow trout infected with L. cyprinacea. Hyperplasia $\left({ }^{*}\right)$, distortion in cartilaginous tissue (arrowed) (a); haemorrhages $(*)$ and hyperplasia at the base of the gills (arrowed) (b); degeneration and necrosis in the skeletal muscle, infiltration of inflammatory cells in the dermis $\left(^{*}\right)(c)$; skeletal muscle granuloma like growths formed by collagen fibrils of dermis $\left(^{*}\right)(d)$; parasitic sections $\left({ }^{*}\right)$ surrounded by fibrious connective tissue (arrowed) in the necrotic muscle tissue (e); haemorrhages $\left({ }^{*}\right)$ in the eyes (f); the cystic structure $\left(^{*}\right)$ in the skeletal muscle $(g)$; desquamation of mucosal epithelium in the intestine (arrowed) (h). 
plasia at the base of the gills (Figure 3b); thickening of dermis, degeneration and necrosis in the skeletal muscle, infiltration of a massive number of inflammatory cells in the dermis and skeletal muscle (Figure 3c); granuloma like growths formed by collagen fibrils of dermis (Figure $3 \mathrm{~d}$ ) and also parasitic sections surrounded by fibrous connective tissue in the muscle tissue were observed (Figure 3e). Despite the fact that, macroscopically, L. cyprinacea was not detected in the eyes; haemorrhages and mild inflammatory infiltrations in the eyes were observed (Figure 3f). Surprisingly, in the skeletal muscle the cystic structure surrounded by fibrous connective tissue (Figure $3 \mathrm{~g}$ ) and desquamation of mucosa epithelium in the intestine was observed (Figure $3 \mathrm{~h}$ ).

\section{DISCUSSION}

Sarı Mehmet Dam Lake is the largest dam in the province covering an area of 1020 hectares and the pearl mullet is present (27). In recent years, cages have been placed on the dam reservoir for trout farming. For this reason, fish diseases in this region are important.

L. cyprinacea is an extremely harmful copepod ectoparasite found on the skin and gills of fresh water fish species and is known to be a causative agent of lernaeosis. This parasite is known as an opportunistic ectoparasite of crucian carp (6). In Turkey, many studies have been conducted on lernaeosis $(10,17-22)$ but none were based in the Sarı Mehmet Dam Lake/ Van. Koyun and Atıcı (23) reported detection of L. cyprinacea on siraz fish (Capoeta capoeta) in Karasu Creek/Van. The study found that carp fish carry this parasite because the Karasu Creek feeds from the Sarı Mehmet Dam Lake. As reported by Grabda (7) this study shows that rainbow trout is extremely sensitive to L. cyprinacea.

The gross pathology observed in our findings bears similarities to lernaeosis in various freshwater fish species $(5,10,12,15,22)$. Especially, haemorrhagic and ulcerative skin lesions, loss of scales and oedema were similar to those in the findings of Berry et al. (12) in rainbow trout infected with L. cyprinacea.

The most significant factor in the spread of the disease is water temperature and water supply. From this point of view, the water source to which the event reported by Koyun and AtıcI (23) occurred is the water passage to the region where this work is carried out. Therefore, this parasitic infestation, which is more common in carp species, was transmitted by the water source and caused the same infestation in the trout. The water temperature measured during the collection of samples was calculated as $23 \mathrm{C}^{\circ}$. The optimum water temperature for infestation is $24-25 \mathrm{C}^{\circ}$.

Although mass mortalities have been reported in small fish, in this study mass deaths were detected because of the intense prevalence of rainbow trout (300-350 g) (13). Attachment was most commonly found in the caudal and abdominal regions. In this study, the parasite was not detected microscopically and histopathologically in the fish gills and head region. However, studies carried out by other researchers have shown that parasites have also been found in the gills $(11,12,23)$. It is worth noting that in this study, histopathologically, hyperplasia, an increase in mucous cells at the distal end of primary lamella, vacuolization in secondary lamella, necrosis of gill epithelium and distortion in cartilaginous tissue were observed.

Histopathologically, in this study significant pathological lesions were reported in the skin and skeletal muscle. Although Mirzaei (14) reported pathological lesions in the liver and kidney of infected fish, in this study desquamation of mucosa epithelium was observed in the intestine. This result may be due to secondary infection as reported by other researchers $(8,12)$. Degeneration and necrosis in the skeletal muscle, infiltration of an extremely large number of inflammatory cells in the dermis and skeletal muscle, thickening of dermis, granuloma like growths formed by collagen fibrils of dermis and also parasitic sections surrounded by fibrous connective tissue in the muscle tissue were observed in the present study as in the other described reports $(11,12,15,16)$. In addition to these findings, distinct cystic structures surrounded by fibrous connective tissue were observed in the skeletal muscle.

\section{CONCLUSION}

In conclusion, our paper is the first to describe cases of lernaeosis on rainbow trout from the Sarı Mehmet Dam Lake in Van-Turkey. Especially in parasitic infestations, prevention of disease is more important than treatment. For this reason, water temperature change times and stock intensity is of great significance as a precaution in aquaculture. In the case report, slow water flow and relatively high water temperature provide a suitable environment for L. cyprinacea. Exposure to these factors together with heavy parasitosis caused mass mortality on rainbow trout from the Sarı Mehmet Dam Lake/Van.

Conflict of Interest: The authors have no conflict of interest to declare.

\section{REFERENCES}

1. Bond NR. Observations on the effects of the introduced parasite Lernaea cypriniacea on a lowland population of a small native Australian fish, mountain galaxias Galaxias olidus. Victorian Naturalist 2004; 121: 194-8.

2. Nagasawa K, Inoue A, Myat S, Umino T. New host records for Lernaea cyprinacea (Copepoda), a parasite of freshwater fishes, with a checklist of the Lernaeidae in Japan (1915-2007). J Grad Sch Biosp Sci 2007; 46: 21-33.

3. Marina H, Beatty SH, Morgan DL, Doupé RG, Lymbery AJ. An introduced parasite, Lernaea cyprinacea $L$., found on native freshwater fishes in the south west of Western Australia 2008; 91: 149-53.

4. Piasecki W, Goodwin AE, Eiras JC, Nowak BF. Importance of copepoda in freshwater aquaculture. Zool Stud 2004; 43(2): 193-205.

5. Plaul SE, Romero NG, Barbeito CG. Distribution of the exotic parasite, Lernaea cyprinacea (Copepoda, Lernaeidae) in Argentina. B Eur Assoc Fish Pat 2010; 30(2): 65-73.

6. Noga EJ. Fish Disease Diagnosis and Treatment. $2^{\text {nd }}$ ed. USA: Watsworth Publishing Co; 2010. [CrossRef]

7. Grabda J. Lerneoza-Lernaeosis. Gospodarka Rybna 1955; 7: 23-4. 
8. Hoffman GL. Parasites of North American freshwater fishes. $2^{\text {nd }}$ ed. USA: University of California Press; 1999.

9. Hassan M, Beatty SJ, Morgan DL, Doupé RG, Lymbery AJ. An introduced parasite, Lernaea cyprinacea $L$., found on native freshwater fishes in the south west of Western Australia. J R Soc West Aust 2008; 91(2): 149-53.

10. Koyun M, Ulupınar M, Mart A. First record of Lernaea cyprinacea L. 1758 (Copepoda: Cyclopoida) on Cyprinion macrostomus Heckel, 1843 from Eastern Anatolia, Turkey. Biharean Biologist 2015; 9(1): 44-6.

11. Innal D, Avenant-Oldewage A, Dogangil B, Stavrescu-Bedivan MM, Ozmen O, Mavruk S. Susceptibility of endemic and non-indigenous fish to Lernaea cyprinacea (Copepoda: Lernaeidae): a case study from Düger Spring Creek (Burdur-Turkey). B Eur Assoc Fish Pat 2017; 37(3): 101-8.

12. Berry JCR, Babey GJ, Shrader T. Effect of Lernaea cyprinacea (Crustacea: Copepoda) on stocked rainbow trout (Oncorhynchus mykiss). J Wildlife Dis 1991; 27(2): 206-13. [CrossRef]

13. Abbas F, Ashraf M, Hafeez-ur-Rehman M, lqbal KJ, Abbas S, Javid A. Lernaea susceptibility, infestation and its treatment in indigenous major and exotic Chinese carps under polyculture system. Pak J Zool 2014; 46(5): 1215-22.

14. Mirzaei M. Prevalence and histopathologic study of Lernaea cyprinacea in two species of ornamental fish (Poecilia latipinna and Xiphophorus helleri) in Kerman, South-East Iran. Turkiye Parazitol Derg 2015; 39(3): 222- 6. [CrossRef]

15. Bednarska M, Bednarski M, So Z, Tysiak RP. Invasion of Lernaea cyprinacea in rainbow trout (Oncorhynchus mykiss). Acta Scientiarum Polonorum, Medicina Veterinaria 2009; 8(4): 27-32.

16. Rahnama M, Khedri J, Mokhtari MS, Jamshidian A, Shafiian A, Bamorovat M. Prevalence and histopathologic study of Lernaea spp. (Maxillopoda: Lernaeidae) in Cyprinus carpio fish in Sistan and Baluchestan, Southeast Iran. Sci Parasitol 2016; 17(1-2):43-8.
17. Burgu A, Oğuz T, Körting W, Güralp N. İç Anadolu'nun bazı yörelerinde tatlısu balıklarının parazitleri. Etlik Veteriner Mikrobiloji Dergisi 1988; 6: 143-66.

18. Soylu E. Surveys on the parasite fauna of the some fishes in Sapanca Lake. Istanbul University, PhD thesis.1990.

19. Koyuncu CE, Dönmez AE. Mersin bölgesinde yetiştiriciliği yapılan bazı akvaryum balıkları (Poecilidae)'nda rastlanılan Lernaea cyprinacea (Linnaeus, 1758) enfeksiyonu. EÜ Su Ürünleri Dergisi 2006; 23: 265-7.

20. Kir I. The effects of parasites on the growth of the crucian carp (Carassius carassius L., 1758) inhabiting the Kovada Lake. Turkiye Parazitol Derg 2007; 31(2): 162-6.

21. Demir S, Karakişi H. Metazoan parasites of nase (Chondrostoma nasus L., 1758) from Tahtalı Dam Lake (Izmir Province, Turkey). Biharean Biologist 2007; 8(2): 95-7.

22. Innal D, Avenant-Oldewage A. Occurrence of Lernaea cyprinacea on mosquito fish (Gambusia affinis) from Kundu Estuary (Antalya-Turkey). B Eur Assoc Fish Pat 2012; 32(4): 141.

23. Koyun M, Atıc AA. First record of Lernaea cyprinacea (Crustacea: Copepoda) on Capoeta capoeta (Actinopterygii: Cyprinidae) from Karasu Creek (Van) Eastern Anatolia, Biharean Biologist 2018; e171207.

24. Frimeth J. General procedures for parasitology. Thoesen J, ed. Suggested procedures for the detection and identification of certain finfish and shellfish pathogens. American Fisheries Society; 1994. p 4.

25. Bauer ON. Opredelitel parazitov presnovodnych ryb fauny SSSR.T. 3. (Guide to the parasites of the freshwater fish fauna of the USSR. Parasitic Metazoa). Nauka Leningradskoe Otdelenie, Leningrad. 1987. p 583.

26. Culling CFA. Handbook of Histopathological Tecniques (Including Museum Tecnique), $2^{\text {nd }}$ ed. London: Butterworth and Co. Ltd; 1963.

27. Çetinkaya O. Van Gölü havzası su kaynakları ve balıkçıık potansiyeli. Doğu Anadolu I. ve II. Su Ürünleri Sempozyumu; 1996; Erzurum: Turkey 1996. pp 71-83. 